\title{
Analysis of Drinking Water Supply System Improvement Using Fuzzy AHP(Case Study: Subang Local Water Company)
}

\author{
Satrio Budi Prakoso ${ }^{1}$ and Suprihanto Notodarmojo ${ }^{2}$ \\ ${ }^{1}$ Water and Sanitation Infrastructure Management, Civil and Environmental Engineerning Faculty, Institut Teknologi Bandung, 40132, \\ Bandung, Indonesia \\ ${ }^{2}$ Water and Wastewater Engineering Department, Institut Teknologi Bandung, 40132, Bandung, Indonesia
}

\begin{abstract}
Study of infrastructure is required to improve the drinking water supply system, in order to achieve The Long-Term Plan Targets on Water Supply (RPJMN) 2015-2019 concerning 100\% universal and equitable access to drinking water services, in accordance with the purpose of Sustainable Development Goals (SDGs) in 2019. Subang district was selected as a case study of water supply improvement because of the improving development in that area and the population growth rate, influencing the need for drinking water. The purpose study is to determine the problems of drinking water supply system, to analyze alternatives for improving water supply system by performing weighted ranking factors in drinking water supply improvement with AHP method and analyzed by fuzzy logic. The method for water supply system improvement could be performed by looking at influential factors using fuzzy AHP approach to obtain some appropriate alternatives. Technical and operational factors was considered the most influential factor in the improvement of water supply system, followed by management capacity, environment, and financial aspect. Fuzzy method with rule base input approach used in this analysis was influencing the output that became the policy alternative to improve drinking water supply.
\end{abstract}

\section{Introduction}

There were 386 Local Water Company (PDAM) from 542 regional autonomous in Indonesia, where is only $53 \%$ that include in "Healthy" category [2] (BPPSPAM, 2015). drinking water supply in 2015 was not reached the target yet, with $68.87 \%$ proper drinking water access. The improvement of water infrastructure and tool is needed to reach $100 \%$ of drinking water universal access, as what has been expected by Sustainable Development Goals (SDGs) in 2019. The case study of this research was done in Subang District served by PDAM Tirta Rangga as local water company to provide drinking water.

Subang District continues to grow, because of the total population was more than 1.4 million people continues to increase and the economic development in the industrial, transportation, residential, and tourism aspect according to Local Goverment Spatial Plan (RTRW) 2011-2031. The potential availability of water in this area was more than enough to serve the whole population, which used streams, springs and deep wells as a source of raw water.

In this study, Fuzzy AHP approach was done in order to improve drinking water supply. This method is often used in research to improve drinking water supply as the research that was done by [16] Bojan Sradjevic and Medeiros in the year (2008). In Thailand year [18]
(2015), Thungngern has done AHP approach and multicriteria decision analysis (MCDA) in water resources management. [9] Okeola (2012) did the same approach to evaluate the distribution of urban drinking water in Nigeria.

Availability of sanitation infrastructure, in this case drinking water supply system is a basic human need [15] (Setiawati et al, 2013). A water supply management should basically provide services to the public on an ongoing basis whether quality, quantity, continuity, reliability and tariff [4] (de Souza, 2014). Improvement of water supply system requires policy alternative which is based on the factors and sub-factors that influence significantly to the improvement of water supply.

Population growth rate prediction required to know water needs in the future. The fluctuation of water used make an influance to water needs [19] (Trifunivic, 2012). Water used fulfillment should be obtain by water availability and distribution, analyzed with EPANET [13] (Rossman, 2000). Financial aspect evaluation is important in water supply plan to make this system more effective and efficient.

Fuzzy method has been used by [1] Ayunda (2013) to determine policy priorities in improving the performance of local water company. The approach is based on the weighting value by expertise respondents, where linguistics language can be converted mathematically by fuzzy logic method.

Corresponding author: satriobprakoso@gmail.com 
The main problems of water supply management in Indonesia, specially in Subang District dominated by operation technique, strategy for financial management, environment conservation and preventive aspect from development, and management capacity evaluation for resources potential optimalization.

Fuzzy version of AHP presents an approach which aims to improve real water management situation and can be considered to be flexible and robust. Sradjevic study in 2008 said, it has been recomended as a reliable support tool by decision makers in real situation, characterized by the uncertainly of both the problem and the decision maker's expertise and cognitive abilities.

Seeing the potential advantages of Subang Region, that has a lot of water resources potential, many income funds, environmental aspect not only good topography for water supply, but also the magnitude of the stream flow continously for supporting the water production and distribution, and company assets and human resorces potential. By doing this analysis and adjust it to the spatial planning document that have been made by local goverment, the water company can improve the water supply system and handle water distribution problems.

\section{Methodology}

This research was conducted in Subang District, West java Indonesia. Figure 1 shows the water service area in Subang District, provide by 16 water production units supplying for 23 subdistrict. This water supply system improvement was analyzed using Fuzzy AHP approach. AHP has an excess to account all important factors as well as to facilitate opinion and conflict [14] (Saaty, 1980), Figure 2 shows the research methodology flowchart.

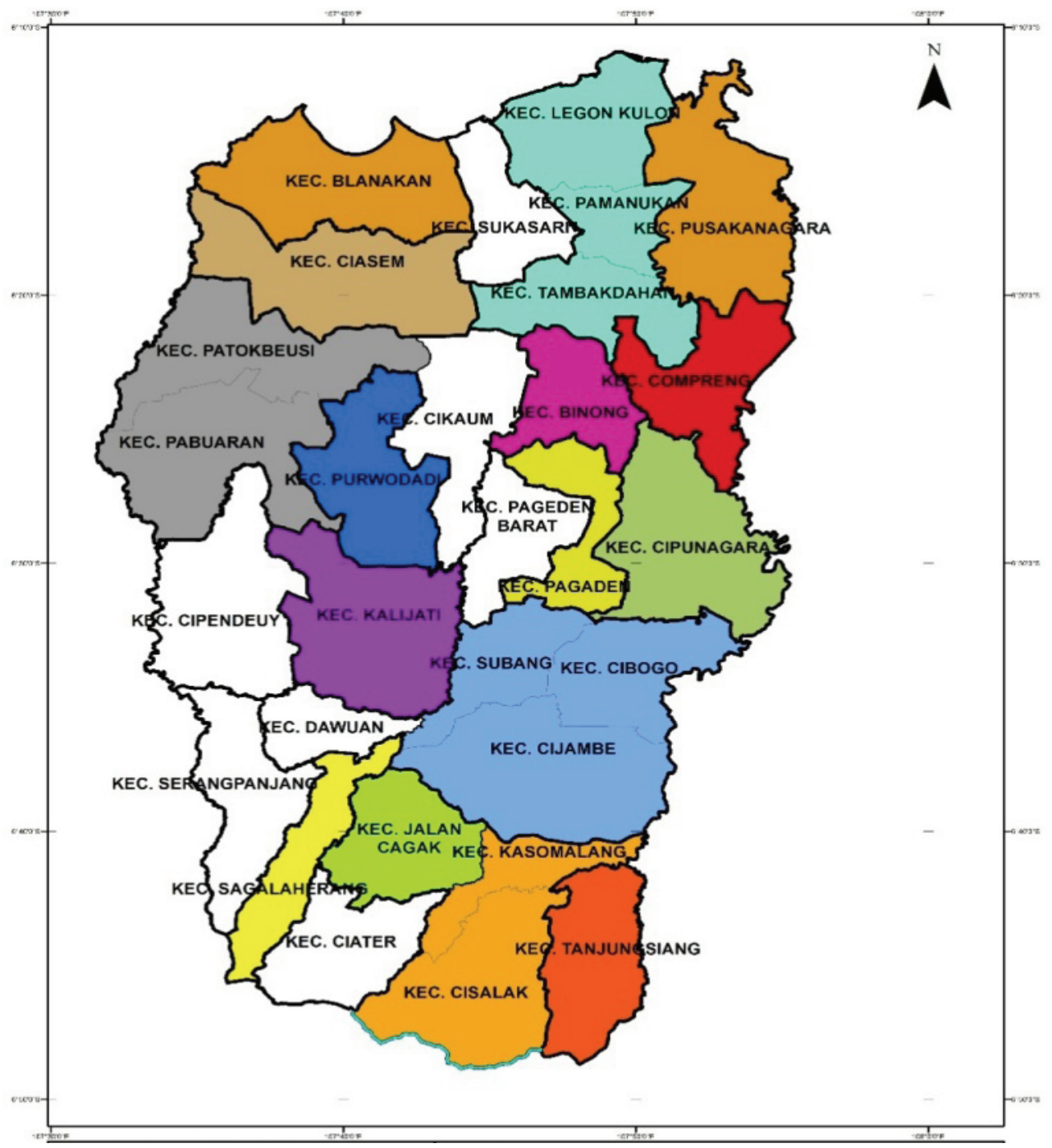

Fig 1. Drinking water supply area in Subang District 
Identification of Drinking Water Supply System Problems

Analysis of drinking water supply improvement alternatives

Collecting data of weighting factors and rulebase Fuzzy

\section{Data Analysis and interpretation}

Fig 2. Research methodology

The initial stage of this research was related to the water supply system by Subang Local Water Company, including literature review, formulating the problem, and field surveys. Basic concepts of water supply system, the distribution by local water company, the company's financial viability, improvement analysis and the basic concept of AHP and Fuzzy logic method will be obtained from literature review.

EPANET 2.0 software was used to measure the piping dimensions of the piping of raw water source to service center distribution, futher find out the output of pipe dimensions and the pumps used [12] (Ramdoni, 2013). In terms of the projected water needs, population projections should be calculated. In this study, population growth rate used 4 (four) projection method. According [5] Gawatre et al (2016), arithmetic method be applied to small town, low economy, with high growth.

While the geometric method used for areas with growth rates that rise rapidly [7] (Jain et al, 2013), moreover exponential and logarithmic were used, where the projection used was the method that produces the smallest standard deviation. Projected water demand using the average daily water needs (Qrh), which is the amount of water needed for one day.

Futhermore, financial analysis of the investment costs incurred for the improvement of planed water supply system in Subang, using investment feasibility methods, which are BCR, IRR, NPV and BEP for financial planning aspect of Subang Local Water Company. Cost analysis was performed to determine company ability in generating benefit from customers.

Based on Regulation no. 232006 the cost could be identify by calculating the rate of Low Cost (TBR), Level of Basic Cost (TBD) and Full Cost Rate (TBP). Water tariffs is not allowed to exceed more than $4 \%$ of people's income customers [6] (Gunawan, 2016).

Drinking water supply system improvement was done by doing Analytic Hierarchy Process (AHP). AHP methodology according to [14] Saaty (2008) have 10 stages, those are: formulating the problem and determining the main objective, determining factors, forming a hierarchical structure, pair wise comparisons, measuring the level of consistency, incorporating the respondent value, weighting factors and analyzing sensitivity. The initial stage was to determine the factors and sub-factors that affect the improvement of water supply system.

Table 1. Factors affecting the improvement of water supply system $[3,4,8-11,15-18,20]$

\begin{tabular}{|c|l|}
\hline Factor & \multicolumn{1}{|c|}{ References } \\
\hline $\begin{array}{c}\text { Operational } \\
\text { Technique }\end{array}$ & $\begin{array}{l}\text { Thungngern (2015), Taylan (2014) Setiawati (2012) Vilanova (2015), Wibowo } \\
\text { (2010), Srdjevic (2008), Okeola (2012) }\end{array}$ \\
\hline Financial & $\begin{array}{l}\text { Meixner (2003), Taylan (2014), Setiawati (2012) Vilanova (2015), Wibowo } \\
\text { (2010), Srdjevic (2008), Okeola (2012) }\end{array}$ \\
\hline Environment & $\begin{array}{l}\text { Thungngern (2015), Meixner (2003), Setiawati (2012), Qu (2016), Srdjevic } \\
\text { (2008), Okeola (2012) }\end{array}$ \\
\hline $\begin{array}{c}\text { Management } \\
\text { Capacity }\end{array}$ & $\begin{array}{l}\text { Taylan (2014), Calabrese (2012), Pangeran (2012), Setiawati (2012), de Souza } \\
\text { (2014), Srdjevic (2008), Okeola (2012) }\end{array}$ \\
\hline
\end{tabular}

Factors that exist in Table 1 was developed into subfactor of each factor. Each of these factors was included in the questionnaires for the weighting factors assessment. Meanwhile, the scale of pair wise comparisons used were as follows Table 2 .

Table 2. Pair wise comparisons scale

\begin{tabular}{|c|c|}
\hline AHP Values & Judgement \\
\hline 1 & Equal importance \\
\hline 3 & Week dominance \\
\hline 5 & Strong dominance \\
\hline 7 & Demonstrate dominance \\
\hline 9 & Absolute dominance \\
\hline $2,4,6,8$ & Intermediate values \\
\hline
\end{tabular}

\footnotetext{
Corresponding author: satriobprakoso@gmail.com
}

Respondents, who were considered to know about the problems of water supply system improvement particularly in the Subang district were 32 of the 50 expertise respondents. Respondents consisted of some stakeholders that were respondents from the local water company as facilitator, Regional body for planning and development (BAPPEDA) as the bureaucracy, and academician as consultant of public works, who were considered capable of representing stakeholders who have a different point of view.

It was according to the research conducted by [10] Pangeran et al (2012). In addition, respondents also came from a group of community leaders as stakeholders to complement the linguistic scale presentations [9] (Okeola, 2012). 
The tabling of weighting value matrix factor 1 to factor 2, and will be divided by 1 reverse valuation of weighting factor 2 to 1 , and so on. The entire weighting value of the series summed by table column, such as equation (1) below.

$A=\left[\begin{array}{cccc}x_{11} y_{1} & x_{12} y_{2} & \cdots & x_{12} y_{2} \\ \cdots & \cdots & \cdots & \cdots \\ x_{N 1} y_{1} & x_{N 2} y_{2} & \cdots & x_{N K} y_{K}\end{array}\right]$

$\mathrm{X}=$ matrix weighting factor assessment results

$\mathrm{A}=$ comparison between factor ratings

Calculation of the value of the priority vectors was done to produce the policy priorities of each factors affecting the improvement in water supply sytem. Multiplication of each value factor in the series was done and then rooted by 4 (four). Vector results between factor divided by the sum of vector, the formula in equation (2).

$\sqrt[4]{ }\left[\begin{array}{cccc}x_{11} & x_{12} & \cdots & x_{1 K} \\ \cdots & \cdots & \cdots & \cdots \\ x_{N 1} & x_{N 2} & \cdots & x_{N K}\end{array}\right]$

$\mathrm{V}=$ vector between factors of results $\sqrt[4]{\text { (root four) }}$ weighting the value of each factor

Network modeling was described by the hierarchy of the factors and sub-factors to determine the weight and the order of factors priority. Weighting results were processed using Expert Choice 11 application, by considering the level of inconsistency. The next step was developing a model analysis to improve drinking water supply with a fuzzy logical approach. The modeling was done with Matlab Fuzzy Toolbox 7.11.

From rule base weight of each factors and subfactors, as well as the results obtained from AHP, it will obtain the weight of drinking water supply improvement on each fuzzy rule base, according to the following equation (3).

$Z=(W 1 Z 1+W 2 Z 2+\ldots . W n Z n) /(W 1+W 2+W n)$

$\mathrm{Z}=$ improvement of drinking water supply system weight

$\mathrm{Wn}=$ the weight of each factor or sub-factor of the AHP results

$\mathrm{Zn}=\quad$ the weight of the risk level of a factor or subfactor in the rulebase

Drinking water supply system factors were converted into a fuzzy set. Membership function used was trapezoidal function Figure 3.

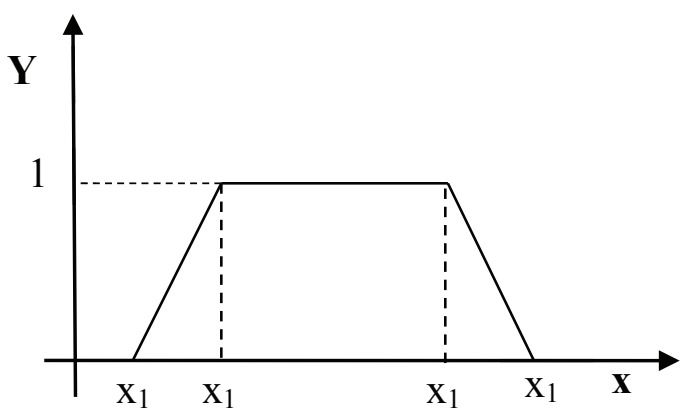

Fig 3. Fuzzy set on rulebase trapezoid

Membership function:

$\mu(x)= \begin{cases}0 ; & x \leq a \text { or } x \geq d \\ (x-a) /(b-a) ; & a \leq x \leq b \\ 1 ; & b \leq x \leq c \\ (d-x) /(d-c) ; & x \geq d\end{cases}$

Modeling validation was done by looking at the alternative between sub-factors that presented the results of fuzzy modeling. By getting weight validation result between the sub-factors vectors, modeling simulation analysis can be done.. As in the equation (4) and (5) [16] (Sradjevic, 2008), data validation in Figure 4.

$$
\begin{gathered}
\mathrm{A}=\left[\begin{array}{cccc}
x_{11} & x_{12} & \cdots & x_{1 N} \\
\cdots & \cdots & \cdots & \cdots \\
x_{N 1} & x_{N 2} & \cdots & x_{N N}
\end{array}\right], k=1, \ldots, K \\
x i j=\sum_{k=1}^{K} \tilde{a} i k \otimes\left[\sum_{l=1}^{N} \sum_{m-1}^{K} \tilde{a} l m\right]^{-1}, i=1, \ldots, N ; j=1, \ldots,
\end{gathered}
$$

$\mathrm{N}=$ the pairwise comparison of alternative values

$\mathrm{K}$ =rate fuzzy matrix of output decision

$X$ =represents the results of the assessment of fuzzy

A =matrix of alternatives membership sub-factor

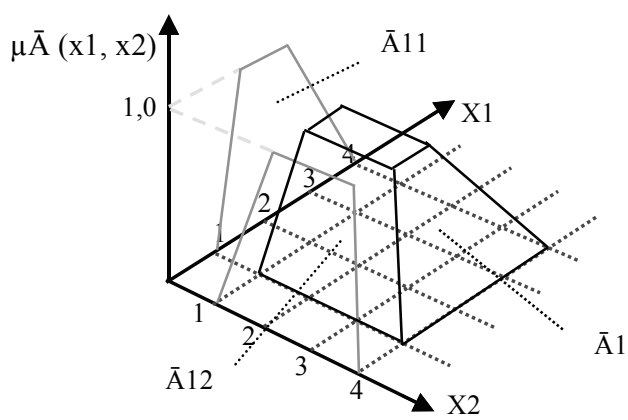

Fig 4. 3D Graphic trapezoidal validation of alternative evaluation 
The next step was to conduct simulation and model application for drinking water supply system improvement based on the available data on the PDAM Subang existing condition, from the fuzzy inference statements (if-then). The results of the application of sub-factors alternative is represented in Equation 6.

$$
Z=\left[\begin{array}{cccc}
x_{11} \otimes y_{1} & x_{12} \otimes y_{2} & \cdots & x_{1 K} \otimes y_{K} \\
\cdots & \cdots & \cdots & \cdots \\
x_{N 1} \otimes y_{1} & x_{N 2} \otimes y_{2} & \cdots & x_{N K} \otimes y_{K}
\end{array}\right]
$$

$y=$ the weight value of the sub-factors of the results of vectorization sub-factor

Fuzzy methods has been used for a variety of specific applications in decision making problems, including. The method used in this study is a group fuzzy with detailed explications of two proposed improvements, namely, a consistency analysis of experts opinions and using a difference technique regarding to handle uncertainties of applying a group decision making to substantiate the advantages and differences, by simulating result intrepetation. AHP fuzzy process, each stage seen in Figure 5.

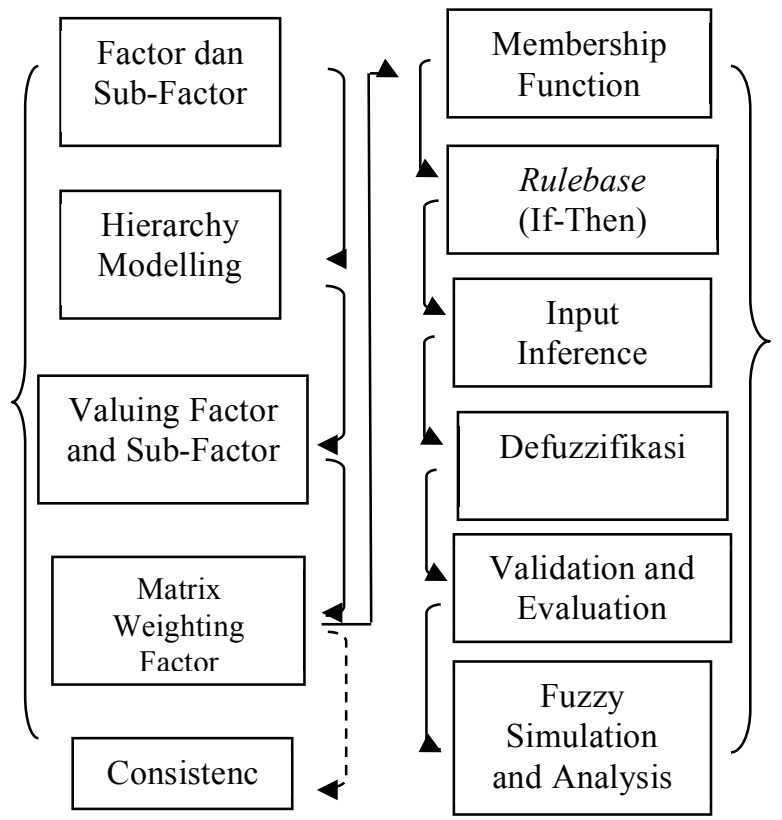

Fig 5. Stages fuzzy AHP increase in SPAM

\section{Results and discussion}

\subsection{Identification of PDAM Subang Problems}

Subang District is an area in the northern districts of West Java Province. Based on the data from Subang Department of Population and Civil Registration, Subang District total population in 2015 was $1,576,042$, with $1 \%$ per year population growth rate from 2010 to 2015. Coverage of drinking water supply system by Subang local water company in 2015 was $16.97 \%$, or for regional coverage was $52.48 \%$. Engineering was needed for water loss that continues to increase.

\subsection{Technical Analysis Distribution System Improvement Study Areas}

Analysis of water distribution scheme was done based on the source of raw water, the flow of rivers, springs and deep wells. 11 districts out of 23 districts served by the unit of production sourced from streams. Most of the production units using raw water from deep wells (deep well). Springs have great potential in terms of quantity, continuity, and quality for multiple production units. Three unit from 16 units was selected for analysis of the production services and the hydraulic pressure using EPANET 2.0 software. 


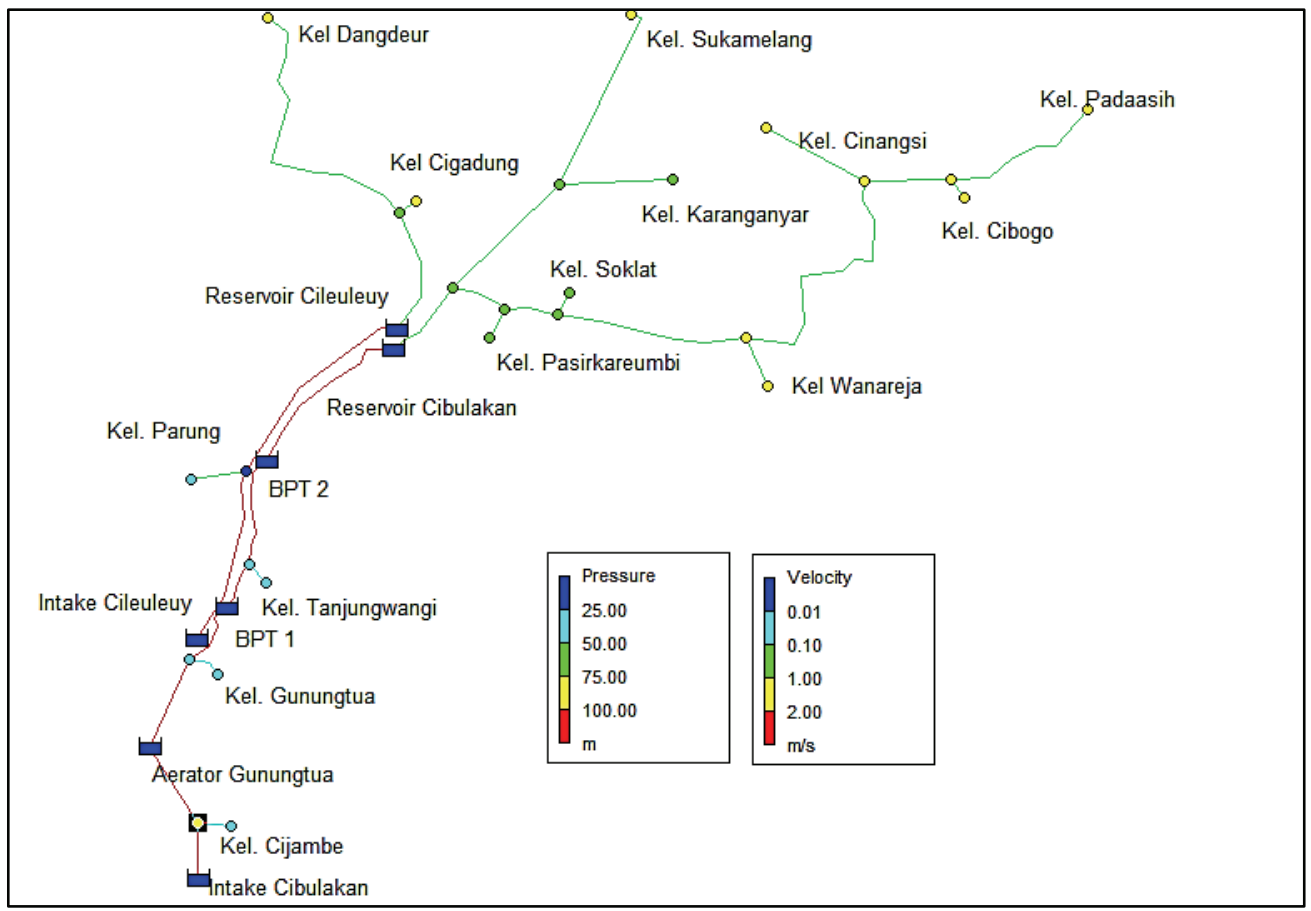

Fig 6. The Epanet simulation results of Subang Unit

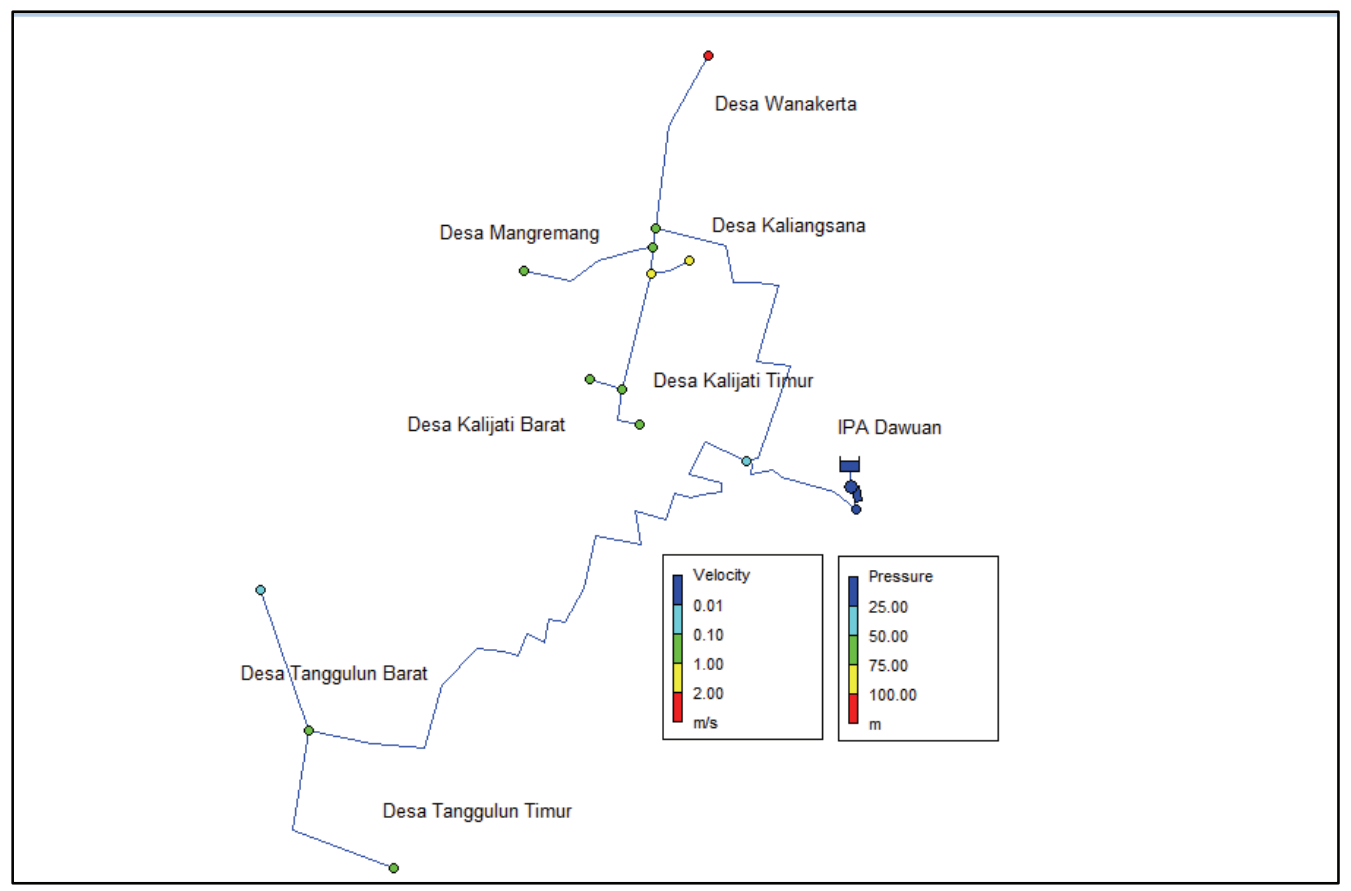

Fig 7. The Epanet simulation results of Kalijati Unit

\footnotetext{
Corresponding author: satriobprakoso@gmail.com
} 


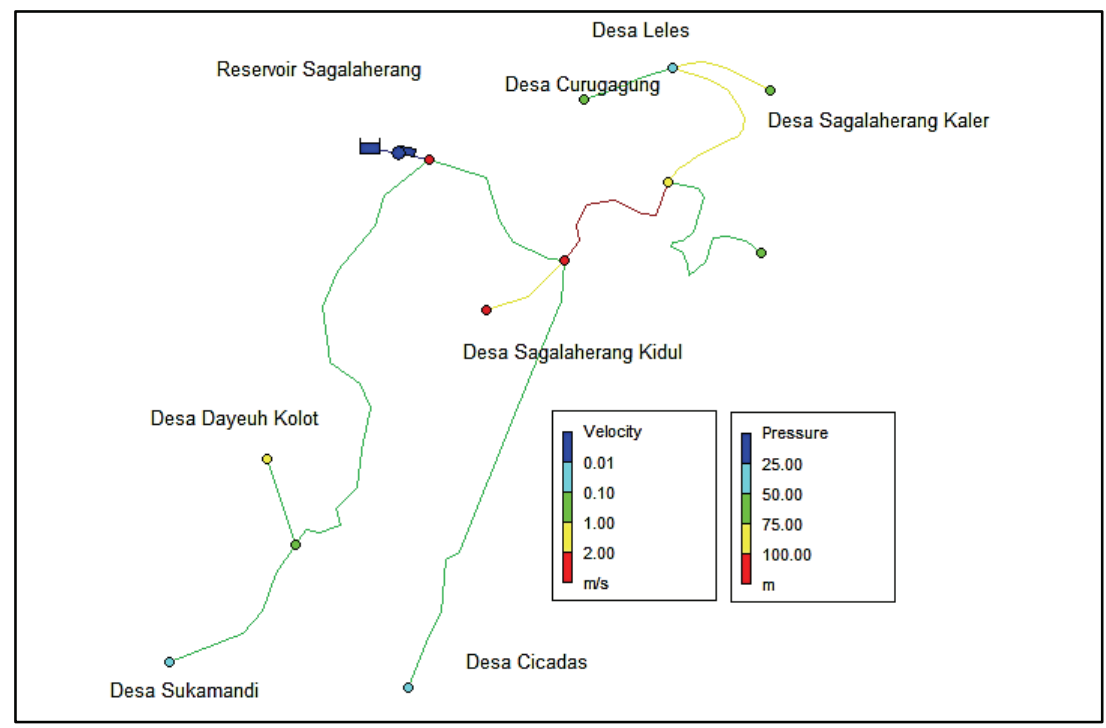

Fig 8. The Epanet simulation results of Sagalaherang Unit

In the simulation model of Epanet on the number of customers adjusted to the target of $100 \%$ service by piping systems. In Figure 6 , a need to increase the production capacity of existing condition, based on the analysis of water availability was not sufficient for drinking water supply. Based on Epanet simulation results, the pressure throughout its service area met the standard in Ministry of Public Works Regulation no. 18, 2007 (more than $10 \mathrm{~m}$ ). In Figure 7, the flow velocity in the pipe did not meet the standard of $0.3 \mathrm{~m} / \mathrm{s}$, the piping was required to be engineered. The addition of pump power was done in Figure 8, in order to achieve the specified pressure.

\subsection{Calculation of Drinking Water Consumption Improvement Planning}

Based on the analysis of drinking water supply planning projections for 20 -year, it was discovered that at the end of the planning, drinking water needs to increase to $1,287 \mathrm{l} / \mathrm{s}$. Domestic demand is predicted to increase from 40.420 house connection at the end of 2015 to 195.621 house connection, and non-domestic from 1214 connection to 4872 connection in the late years of planning, it is necessary to increase production capacity gradually from the existing condition in the range of $4501 / \mathrm{s}$ to reach the service $100 \%$.

\subsection{Financial Aspects of Water Supply System}

Anchored Ministry of Internal Affairs no. 23 in 2006, the ability to pay the basic needs of drinking water does not exceed $4 \%$ of public revenue.

Table 3. Determination of water tariff

\begin{tabular}{|l|r|r|r|}
\hline & Tariff Alternative I & Tariff Alternative II & \multicolumn{1}{c|}{ Tariff Alternative III } \\
\hline NPV & Rp $18,681,880,130$ & Rp $152,272,709,745$ & Rp $168,298,479,549$ \\
\hline BCR & 1.01 & 1.08 & 1.09 \\
\hline BEP & 17.39 & 14.13 & 12.13 \\
\hline HPP & Rp 4.,117 & Rp 4.117 & Rp 4,117 \\
\hline
\end{tabular}

Judging from the financial feasibility in Table 4, the alternative tariff III (three) fare better than others, with NPV and BCR's largest and fastest-year return of capital.

\subsection{Selection Analysis and Weighting Method with AHP}

*Corresponding author: satriobprakoso@gmail.com
Questionnaire was a process of verification after identifying each factor, the number of respondents was 27 expertise respondents. The entire sub-factors were influencing water supply system improvement in Subang district, with the value for each factor was above $65 \%$.

The final results of the paired comparison questionnaire were inputted into the AHP model with Expert Choice 11 Program, which begins by describing paired comparisons matrix, as seen in Figure 9. 


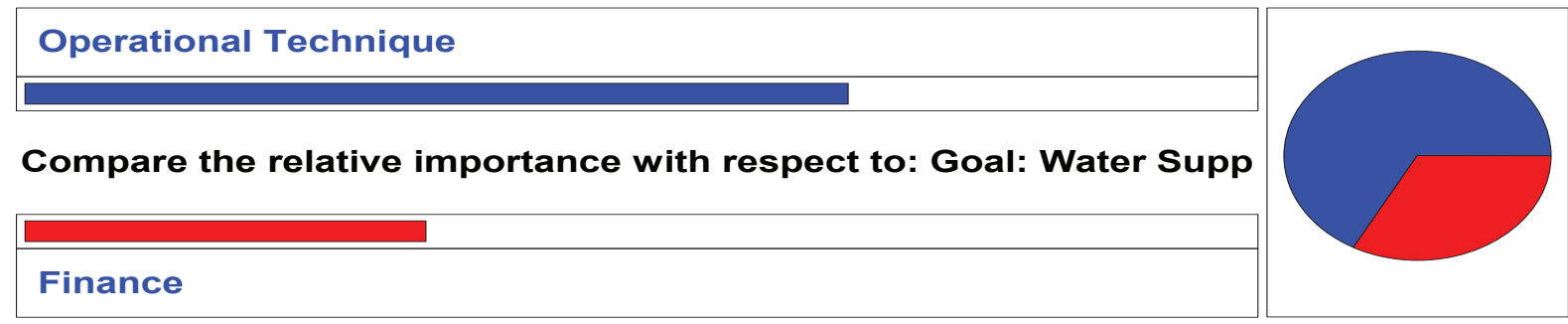

\begin{tabular}{|l|r|r|r|r|}
\hline & Operational & Finance & Environmer & Managemer \\
\hline Operational Technique & & 2,03 & 2,79 & 1,34 \\
\hline Finance & & & $(1,07)$ & $(1,33)$ \\
\hline $\begin{array}{l}\text { Environment } \\
\text { Management Capacity }\end{array}$ & & & 1,48 \\
\hline
\end{tabular}

Fig 9. Paired comparisons matrix between factors

Next was analyzing the weighting value between the factors and sub-factors to make a ranking by 33 respondents experts, this was the output of the matrix calculations.
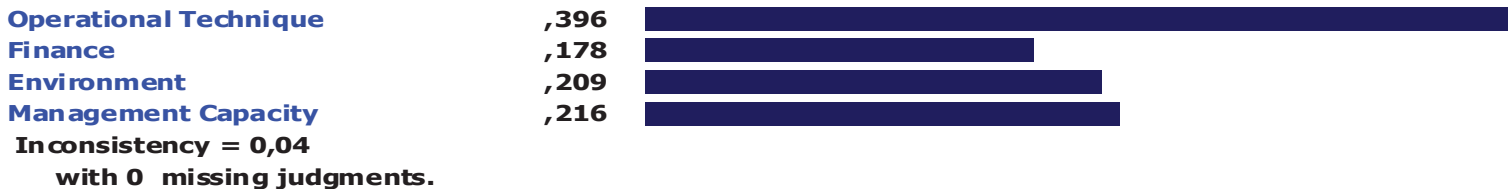

Fig 10. The value of weighting among factors

The most influential factor to improve the water supply system in Figure 10 was operational technique with the weight value was 0.39 , then capacity of management environment, and financial. This factor inconsistencies rate was 0.04 , where the rate was below 0.1 so that results and expertise can be justified [12] (Romdoni, 2013). The management of drinking water supply systems was not considered a good operational technique, and require priority improvement.

\subsection{Analysis of Water Supply Improvement Model with Fuzzy Method}

The identification results of the questionnaire, resulting in 22 sub-factors that need to be examined in this modeling. Sub factors were included into four main factors, those were operational technique, financial, environment, and management capacity, which from these four factors form several sub-models of water supply system improvements. Rule base design of water supply improvement analysis model was the most important stages before performing fuzzy rule base. The concept of the model structure of drinking water supply system improvement can be seen in Figure 11.

\footnotetext{
*Corresponding author: satriobprakoso@gmail.com
} 


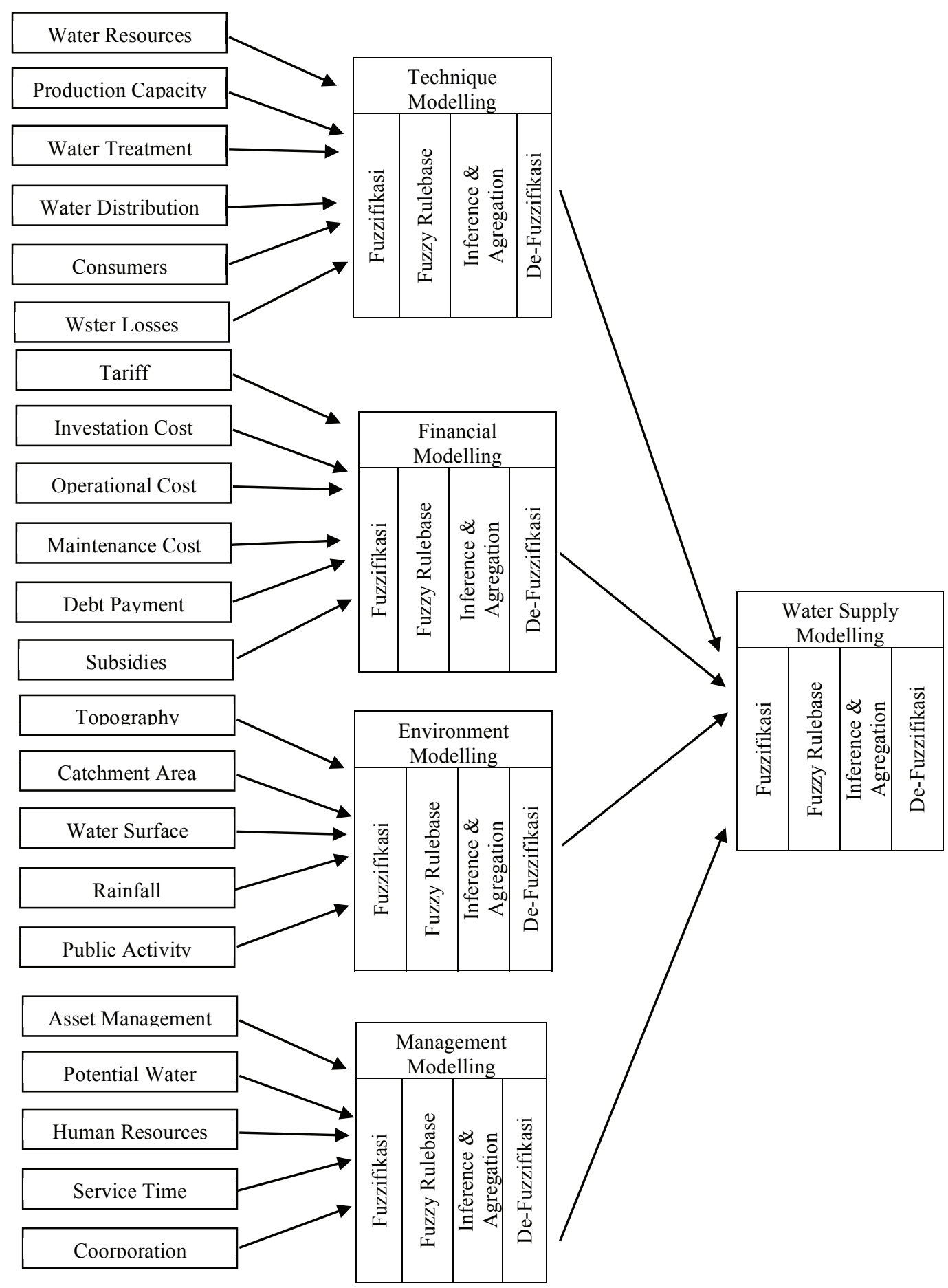

Fig 11. Structure of drinking water supply improvement fuzzy rulebase model

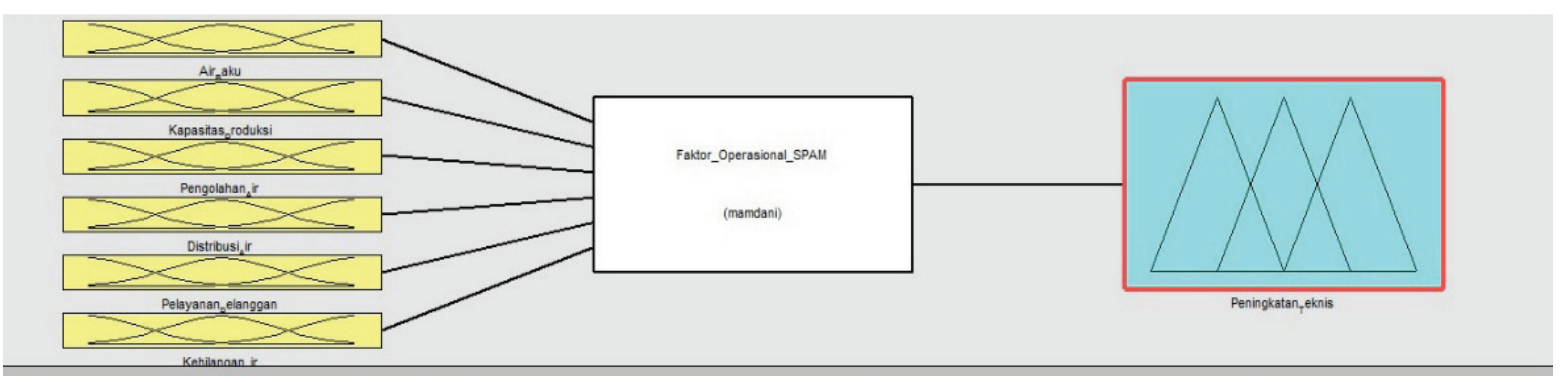

Fig 12. Operational technique fuzzy model 
First set of fuzzy models as Figure 12. The next step was validating the model by incorporating fuzzy rulebase into sub models, to review the three- dimensional graphic, as shown in Figure 13, for example validation of modeling is done.

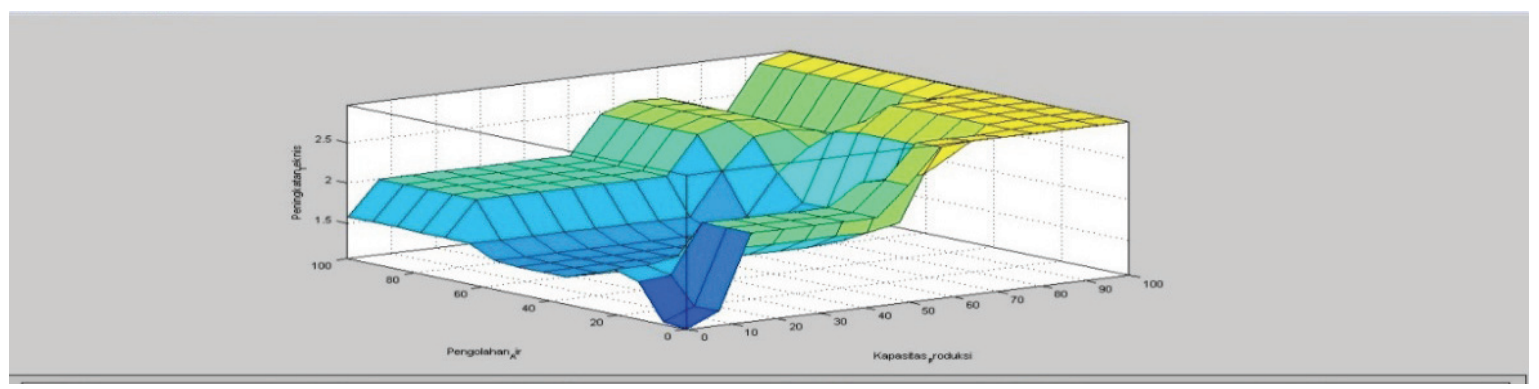

Fig 13. 3D graphic between water production and processing

It can be seen from Figure 13, that the water production capacity will continue to improve the operational technique of drinking water supply. Improvement of operational technique was initially influenced by water treatment process, but that pattern changed to be declivous after entering 30\% fulfillment of water quality standards. The improvement in production capacity trend was also always followed by the improvement of water treatment, although it not sharp.
Drinking water supply system improvement model has been designed, simulated with existing data and improvements planning in Subang District Local Water Company. Simulation of the model was done by using the current scenario/existing and future scenarios that had an improved water supply system.

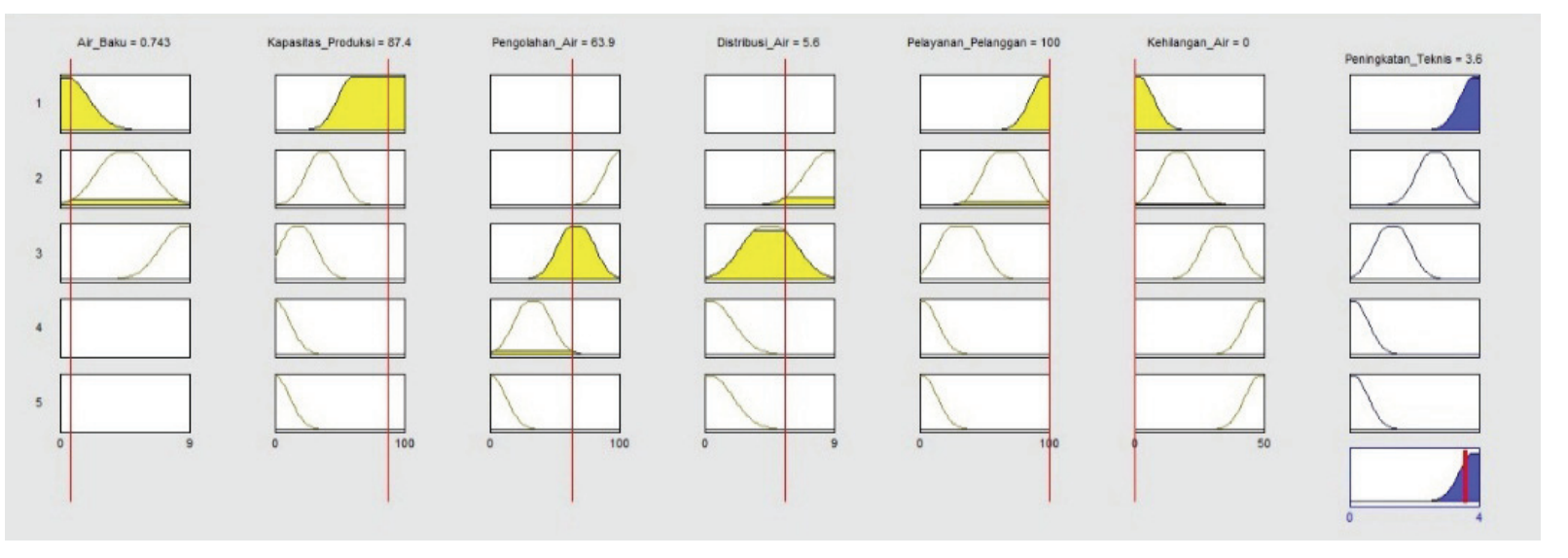

Fig 14. Operational technique improvement model simulation

In Figure 14, improvement of operational techniques will be able to approach the optimal number at 3.6 of 0 to 4 , if drinking water supply system utilize the capacity of the water from streams, capable of producing water with a large capacity, capable of achieving $80 \%$ quality standards of raw water treatment efficiency, use gravity in the distribution system, and unavailable water losses.
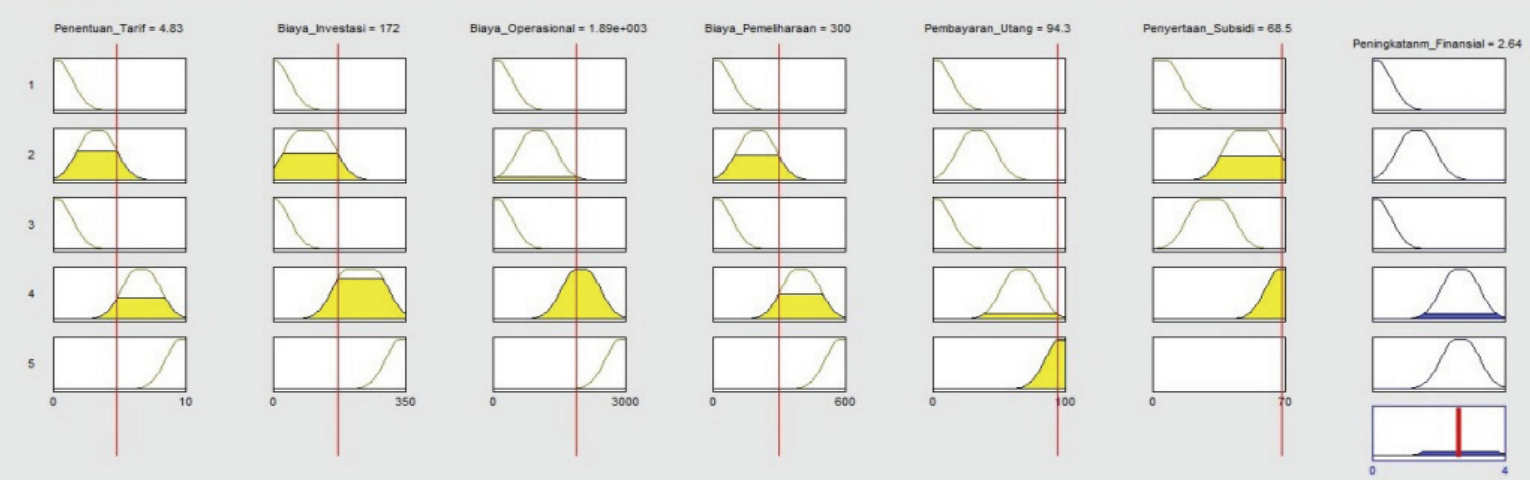

Fig 15. Financial improvement model simulation

\footnotetext{
* Corresponding author: satriobprakoso@gmail.com
} 
The results of the simulations showed that using low tariff will be able to influence the improvement of drinking water supply system, which can increase the number of customers of local water company, as shown in Figure 15. This tariff was not maximized, futher it only able to reach 2.64. At the maximum point of the investment, operation cost, maintenance cost, if it supported the ability to pay off debt and aided by $70 \%$ government subsidies.

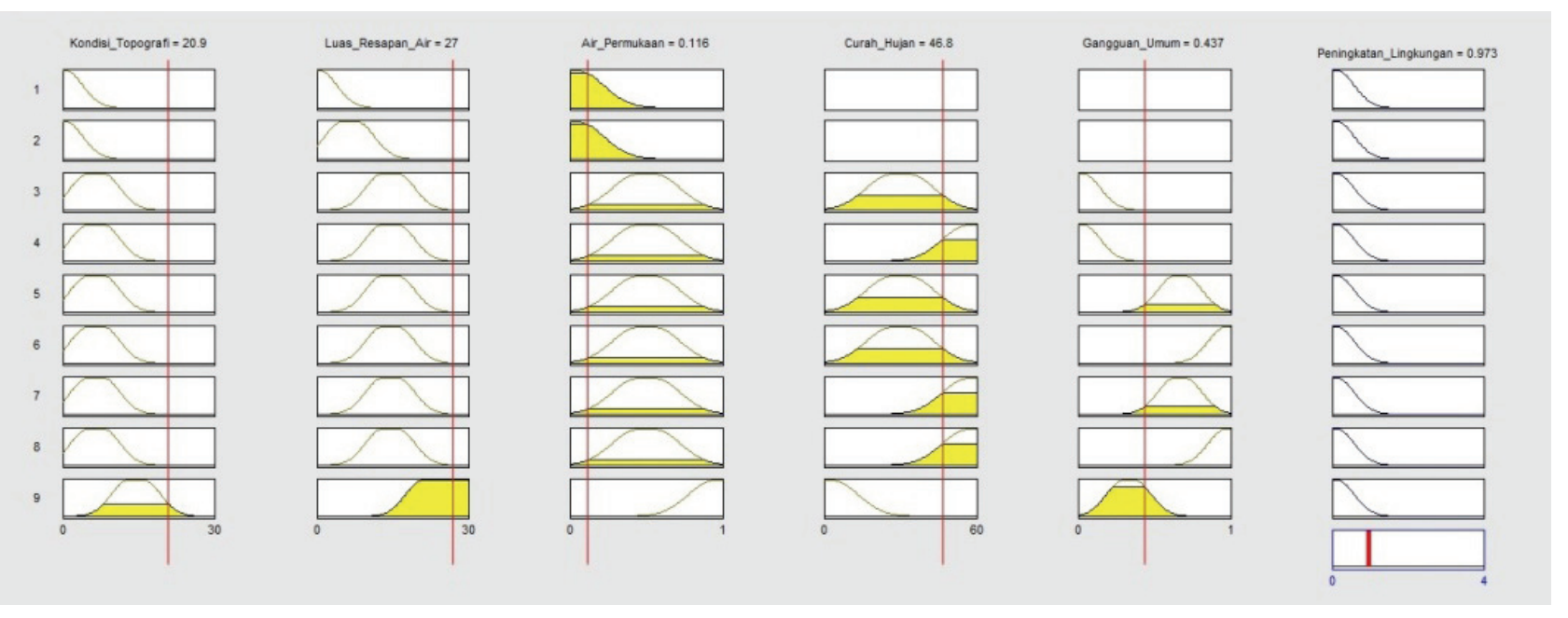

Fig 16. Environmental improvement model simulation

In the analysis of fuzzy, the improvement of environmental factors cannot be the main policies alternative to improve the water supply system. Although it has been serving the high topography area, which facilitate gravity flow system, in an area that has a high water catchment, maximizing the potential of the river flow, in the high rainfall area, and avoid disruption to the traffic and the industrial, environmental improvements didn't have the high-value it was just 0.973 as in Figure 16.
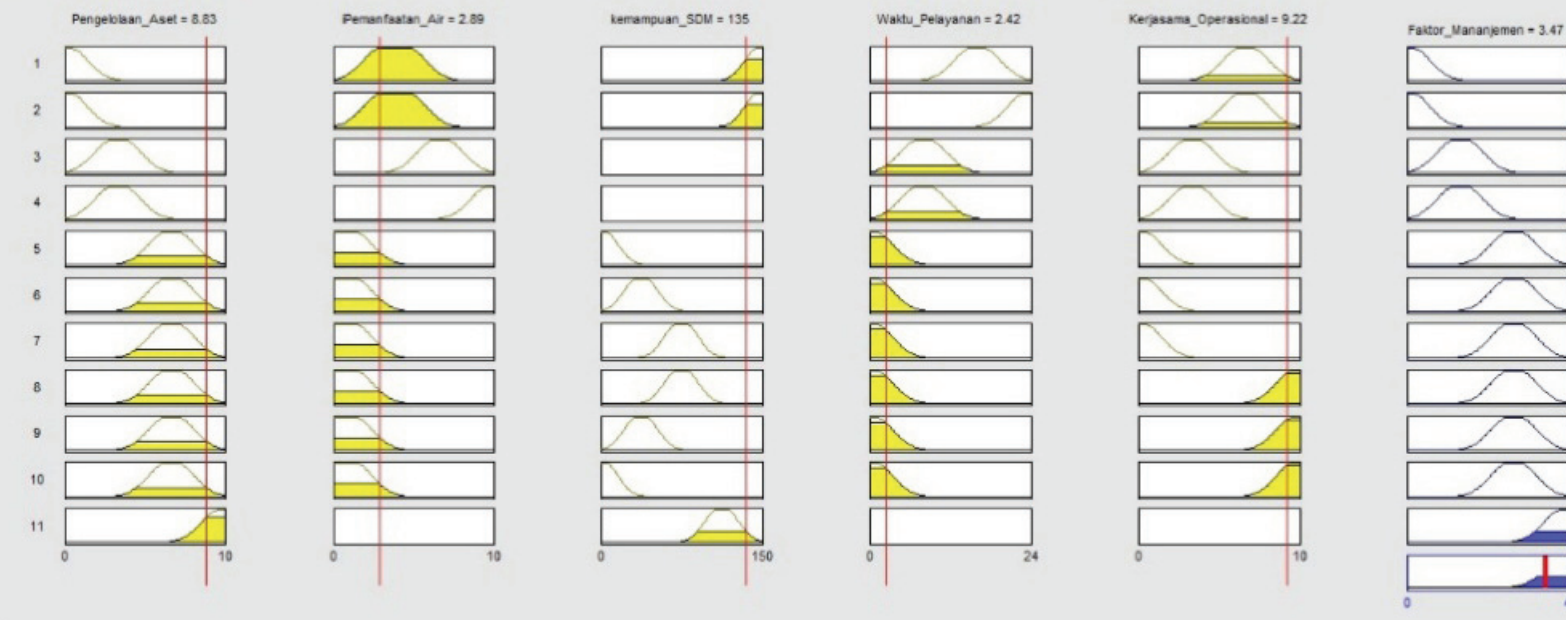

Fig 17. Management capacity improvement model simulation

Fuzzy modeling analysis in Figure 17 shows that asset management that able to provide maximum income, river water utilization, upgrading, the service time over 20 hours, and cooperation with funding supporting partners, will be able to improve water supply systems management. The Fuzzy AHP method output in this study was for water supply improvemnt, which is able to be the base of decision making in infrastructure development.

AHP method approach showed operational technique was become first priority in policy, as in the master plan of water supply (RISPAM) Subang District, that weight focusing about operational problems. Water supply improvement plan with water resource potential optimalization, water production capacity improvement, water losses reduction, and provide a wider water access, it can help achieving SDGs target in operational technique, determined by fuzzy model.

Level of financial improvement would be very high if able to investment increasing, by tarif allocation about a half and $10 \%$ for maintenance cost, and overcame the debt problem. Water distribution with gravitation used in environmental support factor, whereas management capacity would be extreamly lift by doing exercise, study, and evaluation to human resorces, for supporting not optimalization assets. Environment aspect naturally

* Corresponding author: satriobprakoso@gmail.com 
as one of company management responsibility, except water supply technique operational system of local water company.

Fuzzy AHP method be able to accomplish water supply system in addition to conventional method, which are distribution pipeline network financial analysis. Improvement of water supply made by policy based on this decision making tools.

\section{Conclusion}

Until 2015, PDAM Tirta Rangga Subang District reached $52.48 \%$ service coverage, although it has high potential sources of raw water. The improvement can be done by the technical and financial analysis. Operational technique factors with the value of 0.3 was considered the most influential factor in the improvement of water supply system, followed by environmental, financial and management capacity.

Modeling simulation analysis of fuzzy AHP is able to answer the problem of drinking water supply development, by utilizing the capacity of raw water from streams, maximizing the production of drinking water, and water losses minimalization. Financial aspect can be very high impact, if the cost of investment, operation, and maintenance would be optimized. Fuzzy method with rule base inputs will affect the output of the drinking water supply improvement alternative, by reviewing the sub-model of factors, based exsisting condition in the case study.

\section{References}

1. Ayunda,N., P.P.K.U.P.K.P.D.A.M.M.Fu.A.H.P. Institut Tekhnologi Surabaya. Jurnal Mahasiswa Matematika Vol. 1, 1. (2013)

2. BPPSPAM. Kinerja PDAM 2015. Kementrian Pekerjaan Umum dan Perumahan Rakyat. Jakarta. (2015)

3. Calabrese, A., Costa, R., Menichini, T., U.Fu.AHP.M.I.C.A. Elseiver Academic Press. Expert Systems with Applications Vol 40, 37473755. (2013)

4. De Souza, E.V., dan Da Silva, M.A. Costa., M.S.E.U.W.S.W.Sup. Procedia Engineering Vol 70, 458 - 466. (2014.)

5. Gawatre, D.W., Kandgule, M.H., Kharat, S.D., C.S.P.F.M. IOSR Journal of Mechanical and Civil Engineering (IOSR-JMCE):, 13, 16-19. (2016)

6. Gunawan, I.A., S.P.P.K.P.P.U.D.A.B.T.O. Institut Teknologi Bandung. (2016)
7. Jain, S., Mishra N., Bokade, S., Chaturvedi, S., A.R.P.F.D.F.S.D.M.M. (IJSR) ISSN: $\mathbf{6 . 1 4}$ (2013)

8. Meixner,O., $\quad$ Fu.AHP.G.D.A.ITS.A.E.E.S. University of Natural Resources and Life Sciences. Vienna, Austria, 1-14. (2003)

9. Okeola, O.G., Sule, B.F., E.Man.A.U.W. Sup.S. M.C.D.M. University of Ilorin. Nigeria Journal of King Saud University - Engineering Sciences Vol 24, 19-24. (2012)

10. Pangeran, M.H., Pribadi, K.S., Wirahadikusumah, R.D., Notodarmojo, S., A.R.M.Cap.Pu.S.O.PPP.S.D.W.Sup.Ind. Civil Engineering Dimension, Vol. 14, 26-35. (2012)

11. Qu,J.,Meng,X.,You,H.,M.S.Ra.E.Tec.A.W.S.P. A.Fu.Gr.D.M.T. Elseiver Academic Press Journal of Hazardous Materials Vol 310, 6881. (2016)

12. Romdoni, Y., Analisis Risiko Kegagalan Jaringan Pipa Distribusi Air Minum dengan Pendekatan AHP-FUZZY. Intitut Teknologi Bandung. (2013)

13. Rossman, L.A., Epanet 2 Users Manual. Environmental Protection Agency. United States.(2000)

14. Saaty, T.L., Pengambilan Keputusan bagi Para Pemimpin. Jakarta: P.T. Pustaka Binaman Pressindo. (1980)

15. Setiawati, E., Notodarmojo, S., Soewondo, P., Effendi,A.,J.,Otok,B.,W.,I.De.S.S.W.S.U.SEM. M. Jakarta. Elseiver Academic Press. Procedia Environmental Sciences Vol 17, 685 - 692. (2013)

16. Sradjevic, B. Medeiros Y., D., P., Fu.AHP.Ass. Wa.M.P.University of Novi Sad. Serbia. Water Resources Management Vol 22, 877-894 (2008)

17. Taylan, O., Bafail, A.O., Abdulaal, R.M.S, Kabli,M.R., C.P.R.A.Fu.AHP.F.TOPSIS Met. Elseiver Academic Press. Applied Soft Computing Vol 17, 105-116. (2014)

18. Thungngern, J., Wijitkosum, S., Sriburi, T., SukhsriC.,A.R.T.An.H.P.:A.App.Wa.R.M.Tha. Chulalongkorn University. Bangkok. App. Envi. Res. Vol 37, 13-32. (2010)

19. Trifunovic,N.,P.R.R.A.W.D.N.,PhDmanuscript, Taylor \& Francis Group. London.UK (2012)

20. Vilanova, M.R.N, Filho, P.M., Balestieri, P.M., P.M.I.Wa.Su.M. Elseiver Academic Press. Renewable and Sustainable Energy Reviews Vol 43, 1-12. (2015) 